His "Abhandlungen über die leichteste und bequemste Methode die Bahn eines Kometen zu berechnen", with a table of eighty-seven calculated orbits, which was made public by Baron F. X. von Zach in 1797, won him universal fame. A second edition was issued in 1847 and a third in 1864. Olbers took up medical practice at Bremen in 1781, but devoted the greater part of each night to astronomy, having fitted the upper portion of his house as an observatory. On January 1, 1802, he rediscovered Ceres, the first minor planet discovered by Giuseppe Piazzi in 1801, and on March 28 observed the second asteroid Pallas, followed by Vesta in 1807. His theory that these planetoids are fragments of a quondam planet, disrupted by internal explosion or by the impact of a comet, was sanctioned by William Herschel, but is no longer accepted. In 1815, Olbers discovered a new comet which bears his name and which has a period of 74 years. He showed that the tail of a comet consists of a filmy vapour driven off from the head by a repulsive force in the Sun, which is now known to be the pressure of solar radiation. He retired from medical practice on January $\mathbf{1}$, 1823, and in 1830, the jubilee of his graduation, he received an honorary doctorate from the medical faculties of Berlin, Bonn and Copenhagen. He died on March 2, 1840, in his eighty-second year.

\section{World Data Centre for Rockets and Satellites, Slough}

A World Data Centre for Rockets and Satellites is now operating at the Radio Research Station of the Department of Scientific and Industrial Research at Ditton Park, Slough, Bucks. This is the third of three centres established under the International Geophysical Year arrangements for centralization of this type of information. Previously there have been rocket and satellite data centres only in Moscow and Washington, and it was agreed at the recent Moscow meeting of the Special Committee for the International Geophysical Year to accept a British offer of a third rocket and satellite centre. The Radio Research Station is an appropriate place for such centres because many satellite experiments are concerned with studies of the ionosphere. Studying the travel of radio waves from satellite transmitters is one way of gaining information about the ionosphere. Research workers at the Radio Research Station and its Singapore sub-station are engaged in such work. Data from the British investigations will be collected by the Slough Data Centre and exchanged with the other data centres in the United States and the U.S.S.R. Information on International Geophysical Year rocket flights and the published reports of investigations will also be collected. All data will be available for inspection and use by workers in the respective scientific subjects under arrangements which apply to all world data centres.

\section{Reorganization of the Admiralty Material Depart- ments}

THE First Lord of the Admiralty announced in the House of Lords on December 19, 1957, a reorganization of the Material Departments under the Controller of the Navy, following upon the report of Sir Barclay Nihill's Committee. The reorganization was completed on October 1 when the new Ship Department was set up. The work of the Controller's departments will then have been reorganized into four large material departments (concerned, respectively, with ships, weapons, aircraft, dockyards and maintenance), each headed by a director-general, and a small group of scientific departments headed by the Chief of the Royal Naval Scientific Service, who will work under the immediate guidance of the Deputy Controller (Research and Development). This group is broadly responsible for basic research and development, the provision of scientific staff and advice to the material departments, and the planning and co-ordination of Admiralty research programmes. Applied research and development will continue to be carried out at the various scientific establishments. The superintendents of those establishments, which will form a part of the supporting services of the new Ship Department, will be responsible for the work of their respective establishments to the Director General, Ships, through the directors of the appropriate professional divisions. The senior scientific officer serving in the Department will act as chief scientific adviser to the Director General and to the directors of Divisions.

\section{B.B.C. Television}

AN interesting addition to the publications of the British Broadcasting Corporation is a booklet entitled "B.B.C. Television-a British Engineering Achievement" (pp. 64. London : B.B.C., 1958. 2s. 6d.). This is a very well produced and copiously illustrated review of the development and present attainments of the Corporation's television service. Reference is made to the early experimental transmissions begun in 1929, and to the report of the Postmaster-General's Television Committee issued in January 1935, which was followed by the opening of the first public television service in the world during the succeeding year. A brief outline of the principles of television is followed by an up-to-date picture of the television facilities which have been built up and are now in use by the B.B.C., with a full description of the new Television Centre now under construction near Shepherd's Bush. A map in colour showing how B.B.C. television broadcasts reach more than 98 per cent of the population, and advice on how to get the best reception of the B.B.C. television service are other items in this booklet. The effects of various forms of interference are also described and illustrated. A mobile television control room is illustrated together with the various methods of telerecording. including the most recent 'vision electronic recording apparatus' (VERA) which will shortly be put into general service. Outside broadcasts account for approximately one-sixth of the B.B.C.'s television programme output. Apart from dealing with activities in Britain, an account of the growth of the international exchange of television prograrnmes known as Eurovision, which was pioneered by the B.B.C. and Radio Diffusion Télévision Française, is supplemented by a map showing the Furovision network.

\section{Electronics, Radio and Telecommunications}

Consmerable progress is being made in the publication of English translations of Russian scientific: and technical literature. Three journals have recently become available published in English translation on the initiative of the Massachusetts Institute of Technology and the Pergamon Institute, assisted by a grant-in-aid from the United States National Science Foundation. One of these is Telecommunications (No. 1, 1957. Pp. 1-94. First English issue. Issued in parts, approximately 1,000 pages per annum. Annual subscriptions: to individuals, 15 dollars 